\title{
Coating Surface Roughness Measurement Made On Coining Dies
}

Tomáš Hanes ${ }^{1}$, Pavol Hvizdoš ${ }^{2}$, Miroslava Ťavodová ${ }^{1}$, Daniela Kalincová ${ }^{1}$, Júlia Hricová1, Pavel Beňo ${ }^{1}$

${ }^{1}$ Faculty of environmental and manufacturing technology, Technical University in Zvolen. Študentská 26, 96053 Zvolen. Slovak Republic. E-mail: tomas.hanes@tuzvo.sk, miroslava.tavodova@tuzvo.sk, daniela.kalincova@tuzvo.sk, julia.hricova@tuzvo.sk,pavel.beno@tuzvo.sk

${ }^{2}$ Institute of Materials Research, Slovak Academy of Sciences. Watsonova 47, 04001 Košice. Slovak Republic. E-mail: phvizdos@imr.saske.sk

The paper describes the surface roughness measurement of functional parts of tools for minting coins. The coining dies were coated with three types of coatings - $\mathrm{CrN}$, TiCrN and WC/C. Roughness of the coining die surface is a very important factor for the quality of a struck coin. The quality of specific coatings on the coining die surface was evaluated by a contact (Hommel Tester T500 roughness measurement device) and contactless method (microscope Sensofar PLu neox) by using optical interferometry and confocal microscopy. Results from the shop measurement gained by using the roughness measurement device were compared to the laboratory measurements gained by using microscope. Moreover, results were illustrated in the graph. Measured values were identical. Only the CrN coating showed bigger difference. Minimum roughness value was measured on the coining die with the TiCrN coating. The WC/C coating reached the maximum roughness value. 3D visualization method of surface roughness using software Gwyddion proved inappropriate for burnished surfaces.

Keywords: roughness, coining die, roughness measurement device, optical interferometry, confocal microscopy

\section{References}

[1] STN EN ISO 4287:1999 Geometrické špecifikácie výrobkov (GPS). Charakter povrchu: Profilová metóda. Termíny, definície a parametre charakteru povrchu.

[2] ŽARNAY, M. a kol., 2013. Konštruovanie 1. Žilina: Žilinská univerzita v Žiline, Strojnícka fakulta, 2013. ISBN 978-80-5540610-7.

[3] NOVÁK, M. 2012. Surfaces with high precision of roughness after grinding. In Manufacturing Technology. ISSN 1213-2489, 2012, vol. 12, no. 12, p. 66-70.

[4] KŘÍŽ, M. 2011. Vliv povrchu na užitné vlastnosti výrobku. In MM Průmyslové spektrum. ISSN 1212-5272, 2011, Vol. 15, No. 7-8, p. 50-51

[5] Böhler K 455 - prospekt firmy. 2013 [online]. [cit. 2013.09.10] Available on the Internet: <http://www.bohler.sk/slovak/files/downloads/023_BOHLER_K455.pdf>

[6] Drsnost' povrchu. 2013 [online]. [cit. 2013.08.21] Available on the Internet: <http://web.tuke.sk/smetrologia/navody/uloha10.pdf>

[7] Sensofar PLu neox. 2013 [online]. [cit. 2013.11.29] Available on the Internet: < http://www.sensofar.com/sensofar/products/plu-neox>

[8] PAWLEY, J. B. 1995. Handbook of biological confocal microscopy. New York: Plenum Press, 1995.

[9] DICKINSON, M. E., BEARMAN, G., TILLE, S., LANSFORD, R., FRASER, S.E. 2001. Multispectral imaging and linear unmixing add a whole new dimension to laser scanning fluorescence microscopy. In Biotechniques. 2001, vol. 31, no. 3, p. $1272-1278$.

[10] ŤAVODOVÁ, M. 2013. Profil povrchu materiálu po rezaní AWJ v 3D vizualizáciách. In Strojárstvo : mesačník o strojárstve. ISSN 1335-2938, 2013, Vol. 17, No. 10, p. 108-109.

[11] čierna, h. - t'avodová, m. 2013. Using the Design of Experiment Method to Evaluate Quality of Cuts after Cutting Aluminum Alloy by AWJ. In Manufacturing Technology. ISSN 1213-2489, 2013, vol. 13, no. 3, p. 303-307.

[12] HRICOVÁ, J. 2013. Influence of Cutting Tool Material on the Surface Roughness of AlMgSi Aluminium Alloy. In Manufacturing Technology. ISSN 1213-2489, 2013, vol. 13, no. 3, p. 324-329.

[13] MADL, J. et. al. 2013. Surface Integrity in Notches Machining. In Manufacturing Technology. ISSN 1213-2489, 2013 , vol. 13, no. 2, p. 188-193.

[14] KROLCZYK, G. - LEGUTKO, S. - GAJEK, M. 2013. Predicting the surface roughness in the dry machining of duplex stainless steel. In Metalurgija. ISSN 0543-5846, 2013, vol. 52, no. 2, p. 259-262.

[15] RAMOS, A. M. - RELVAS, C. - SIMOES, J. A. 2003. The influence of finishing milling strategies on texture, roughness and dimensional deviations on the machining of complex surfaces. In Journal of Materials Processing Technology. ISSN 09240136, 2013, vol. 136, no. 1-3, p. 209-216. 